Ana Campos é investigadora de Centro de Estudos de Teatro.

Cabeçalho da revista Entre Janeiro e Agosto

de 1928 a revista reaparece, sob o titulo Teatro magazine, também dirigida por Mário Duarte, com o mesmo formato inicial e as mesmas caracteristicas. ${ }^{2}$ Nos n.os 45, 49 e 52 as peças publicadas são de autores estrangeiros em. tradução portuguesa.

Todas as remissões para a revista serão feitas

através do ano da publicação e do número entre parênteses curvos.

${ }^{4}$ A empresa De Teatro Editora publicou, entre

outras, obras como Memórias de Eduardo Brazõo, compiladas pelo seu filho; In Memoriam, de Ângela Pinto; Farsa de Inês Pereira, de Gil Vicente, adaptação de Marcelino Mesquita, intróito do

professor António

Pinheiro, marcação e gráficos de Joaquim de Oliveira. Esta casa editorial foi ainda responsável pela

edição da De teatro caricatural, que publicava

mensalmente três caricaturas de actores $\mathrm{e}$ autores conhecidos do público traçadas pela pena de Amarelhe.

\title{
A revista De teatro Uma visão parcial da dramaturgia portuguesa dos anos 20
}

Ana Campos

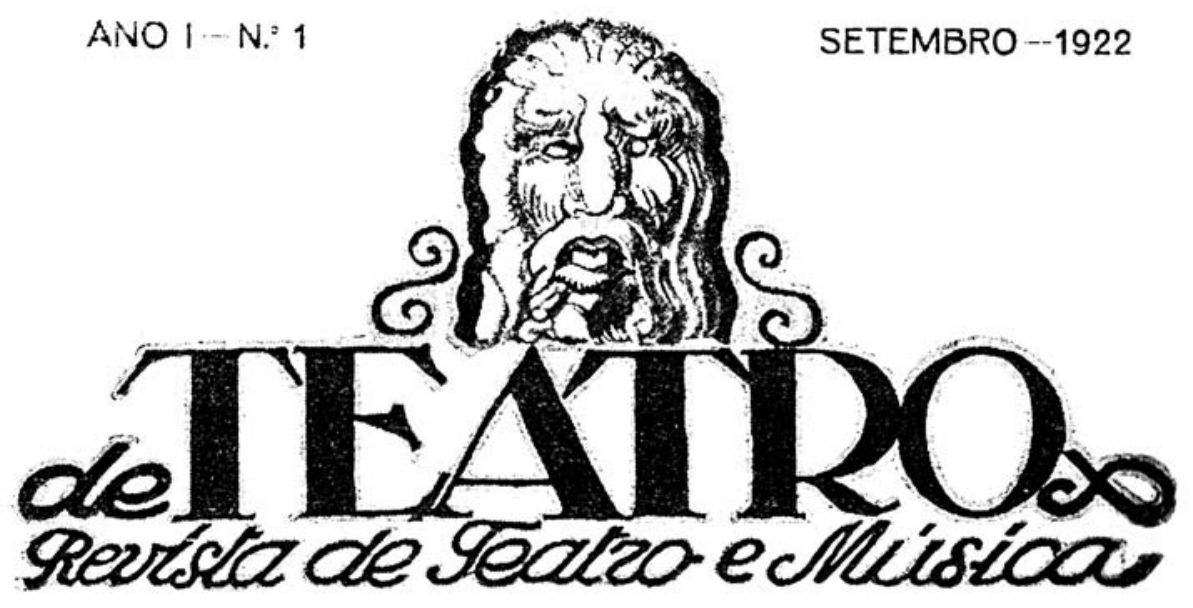

Ao historiar o teatro português contemporâneo desde 0 último quartel do séc. XIX até ao final do séc. XX, Luiz Francisco Rebello definiu quatro momentos distintos: 0 período pré-republicano, entre 1881 e 1910; o período de vigência da república democrática, entre 1910 e 1926; o período da ditadura salazarista, entre 1926 e 1974; e 0 período pós-revolucionário, que se seguiu ao 25 de Abril (Rebello 1984: 7-28). Podemos considerar que a Revista De teatro - Revista de teatro e música é, pelas razões que a seguir se expõem, um órgão de informação fundamental para melhor conhecermos o segundo destes momentos, aí incluindo um entendimento do que era (ou se pensava que era) a dramaturgia portuguesa.

Publicado ininterruptamente entre Setembro de 1922 e Agosto de $1927^{1}$, sempre sob a direcção de Mário Duarte, este periódico mensal dedicado a todos os que de uma forma ou de outra se interessavam por teatro, destacouse pela sua longevidade e por um conjunto de caracteristicas que o individualizaram. Entre elas contamse as seguintes: publicou peças de autores portugueses (excertos de peças inéditas, ou peças completas) ${ }^{2}$, muitas delas já representadas em Portugal, o que leva a direcção da revista a orgulhar-se em 1926 (1926: 40) ${ }^{3}$ de ser a segunda publicação mundial a conseguir tal proeza; desencadeou um debate de ideias sobre o estado do teatro da época para o qual contribuíram inúmeros colaboradores de que destaco Henrique Lopes de Mendonça, André Brun, Carlos Selvagem e Santos Tavares; publicou críticas a cerca de quatrocentos espectáculos levados à cena em Portugal por companhias quer nacionais, quer estrangeiras; noticiou regularmente o que de mais relevante se ia passando nos palcos portugueses; registou com regularidade publicações de teatro; incluiu nas suas páginas fotografias e caricaturas - muitas destas saídas da pena de Amarelhe, mas também da autoria de Almada Negreiros e de outros - de conhecidas figuras do teatro de então; foi peça fundamental para a fundação da Sociedade de Escritores e Compositores Teatrais Portugueses, sob o impulso de Mário Duarte, em 1925; criou a Empresa De Teatro Editora a partir de Dezembro de 1924 que, para além da revista, publicou algumas obras importantes para a história do teatro português ${ }^{4}$.

Procurando reflectir sobre o tipo de dramaturgia que a revista publicava - e, de algum modo, incentivava deparei-me com um corpus bastante vasto e de uma enorme variedade genológica. Com efeito, entre as cerca de sessenta peças publicadas contam-se doze comédias, vinte e três obras apresentadas com a classificação genérica de peças (correspondendo na sua maioria a peças de costumes cuja acção decorre em ambiente contemporâneo), uma peça sacra, três dramas, um drama lírico, um drama 
rústico, um drama íntimo, um ante-acto dramático, uma tragédia-drama social, uma tragédia social, nove operetas, quatro episódios em um acto, uma farsa e uma paródia. Correspondem a peças levadas à cena entre $1874^{5}$ e $1927^{6}$.

Para evitar uma possivel dispersão e no sentido de conferir alguma coerência ao conjunto de reflexões em torno da dramaturgia que se publicou na revista, optei por me centrar nas obras escritas entre 1920 e 1926, excluindo deste conjunto quer as operetas que, por terem uma componente musical bastante acentuada, teriam de merecer outro tratamento, quer os textos de autores estrangeiros.

No estudo desta dramaturgia temos de tomar em consideração o panorama do teatro português deste momento e a realidade cultural que haveria num pais em que $80 \%$ da população era analfabeta, como se apurou aquando da implantação da República. Com um número excessivo de companhias para um público frequentador de teatro declamado cada vez mais escasso (dada a concorrência do animatógrafo, que praticava preços mais acessiveis, e do teatro de revista, de maiores recursos financeiros e capaz de atrair camadas mais vastas da população), estas companhias viam-se na necessidade de estrear peças atrás de peças, em tradução ou feitas por encomenda. Esta situação colocava os autores dramáticos sob a enorme pressão de produzir não para a edição em livro, mas para determinada companhia tendo em consideração o seu elenco que, nas de maior dimensão, era normalmente constituido por um conjunto de tipos fixos: uma dama galã, uma ingénua, um galã, um centro, um pai nobre ou velho sério, um cómico, um centro cómico, um velho e uma velha cómicos, amorosos ou galãs de ponta em papéis secundários, característicos e utilidades (que serviam para substituir qualquer actor que faltasse). Tinham ainda de tomar em conta o gosto do público e a urgência da estreia. Por outro lado, as condições em que as companhias encenavam as suas peças eram também factor de desmotivação para os dramaturgos, uma vez que escasseavam os recursos, repetindo-se, com ligeiras alterações, o cenário de encenação para encenação, num ambiente em que reinava a indisciplina entre os actores, caindo-se assim na repetição de fórmulas já gastas e recorrendo a receitas do - mau - teatro francês:
Chegou-se ao máximo na confecção. Assim:

Adultério (fulcro da acção) - 1500 gr.

Personagens do $2^{\circ}$ plano (ironia e paradoxo simulando critica de costumes) $-500 \mathrm{gr}$.

Numa poção e para tomar em três doses iguais (três actos).

A fórmula, que pode ser transformada em outras de similar combinação e doseamento, é a aconselhada por Wolffe por toda essa legião de dramaturgos picaros que conhecem de cor este outro Chernowiz teatral, aplicando assim fraudulentamente nas suas peças o recipe agora tanto em voga. (1925:38)

Para agravar este estado de coisas, a crítica demitia-se do seu papel regulador do meio teatral, deixando-se levar por simpatias e antipatias pessoais, e o público pouco mais exigia do que algumas horas de entretenimento fácil. Isto leva a que se comente nas páginas da revista que não era por acaso que os espectáculos começavam sempre à hora da digestão.

\section{Os mundos ficcionais}

Vejamos, em resumo, que mundos ficcionais são inventados nas peças publicadas na revista e que ideias veiculam. Focalizarei, então, um conjunto de textos cuja acção decorre em ambiente contemporâneo e que, de algum modo, serve para defender uma tese presa a valores que explicitamente se recomendam.

No geral, a acção das peças gira em volta de casos amorosos, tratando de rivalidades, casamentos de conveniência, consequências da sedução (por homens inescrupulosos ou por mulheres fatais) e infidelidades conjugais. Assim é com a peça A luva de Ricardina (1923: 11) estreada na época de 1922-23 no Teatro Politeama, pela Companhia Rey Colaço - Robles Monteiro. É referida na revista como tendo sido escrita por Ricardo Durão, que, segundo parece, seria não um dramaturgo, mas um oficial do exército que se tomara de amores por uma actriz a quem quis oferecer uma peça, que, entretanto, encomendou a um amigo. A intriga gira em volta de um triângulo amoroso que tem no centro Ricardina, filha de Helena, belissima mulher que, no seu tempo, também foi disputada por dois homens, como Helena de Tróia. É uma jovem inteligente e culta, mas extraordinariamente coquette. Por ela se batem em duelo o Capitão Manuel
${ }^{5}$ Os campinos (1924: 22) de Salvador Marques.

${ }^{6}$ Maria rapaz (1927: 53/54) de Lourenço Rodrigues, Silva Tavares e Xavier Magalhães. 
Actor José Ricardo, desenho de Amarelhe.

Actor Chaby Pinheiro, desenho de Amarelhe.
É curioso verificar a recorrência deste nome para as ingénuas da época, certamente por evocação da Rainha Santa Isabel, como afirma André Brun, que por antonimia o aplicará a uma corista na peça A vizinha do lado.

${ }^{8}$ Norberto de Araújo (1889-1952) publicou em jornais como A Manhã, 0 Mundo e, mais tarde, o Diário de Lisboa tendo-se notabilizado pelas muitas crónicas, entrevistas e reportagens que assinou. Era ainda um profundo estudioso da cidade de Lisboa tendo também publicado nesse domínio.
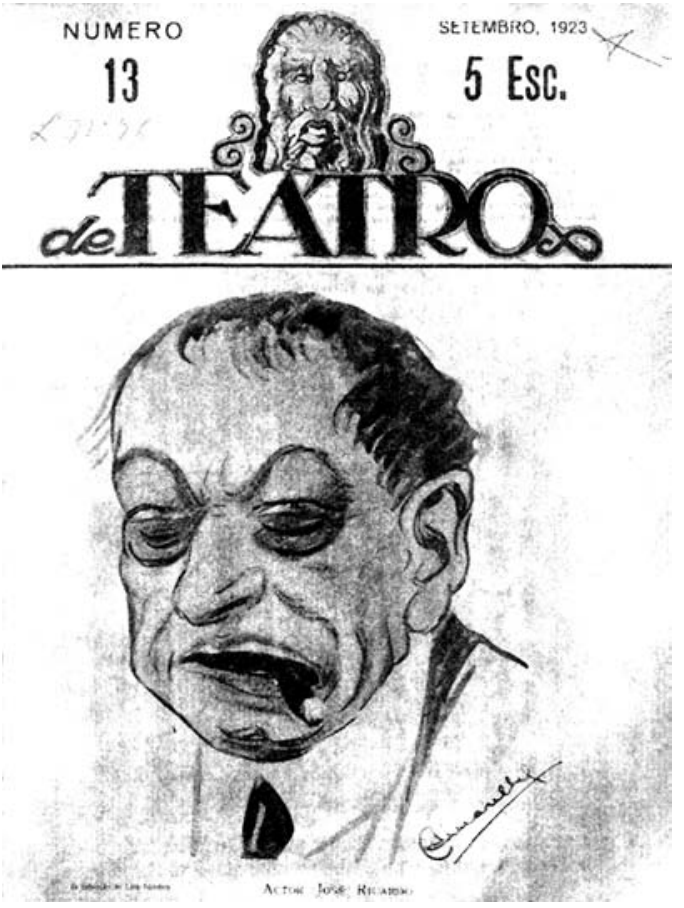

da Cunha, homem de fortes princípios morais, e um homem sem escrúpulos que mantém paralelamente uma amante, e que sairá derrotado do confronto. Pelo meio, abordase a questão da ilegalidade dos duelos - considerados como uma prática reprovável, dando mostras de selvajaria - bem como a condição social da amante desprezada pelo homem que ama mas que apenas a usa para satisfazer a sua volúpia. Outro aspecto importante nesta peça é a revelação da pureza de valores que ainda prevaleceria no campo, por oposição à degradação moral da vida na capital.

A peça Renascer (1923:14) - de Mário Duarte (1890 -1934) e Valério de Rajanto - estreou-se a 28 de Setembro de 1923 no Teatro Apolo, pela companhia Maria Matos Mendonça de Carvalho. Nela os autores apresentam-nos uma familia burguesa abatida pela ruina financeira e para quem a salvação seria o casamento do filho com uma jovem de família aristocrática. Perante o alcoolismo do pai, e face aos negócios obscuros em que este se envolvera, o jovem assume o comando da empresa, afasta a jovem pretendente, que o assedia com uma insistência descabida, e consegue, fazendo valer a sua nobreza de carácter e inteligência, salvar a empresa e o seu amor. Embora seja uma peça de fraco valor literário, é de salientar a apologia da nova geração, fruto de uma época de fracturas bem marcadas, a geração da República, deixando no ar uma interessante questão: que valores para a nova sociedade?

São semelhantes alguns dos traços da intriga que surge na única peça que nos deixou o pedagogo Faria de Vasconcelos (1880-1939): O turbilhão, que se estreou a 21 de Julho de 1924, no Teatro da Trindade pela companhia Berta de Bivar - Alves da Cunha. Nesta peça, de análise social, um jovem par amoroso é contrariado no seu amor pelos pais da jovem Isabel ${ }^{7}$, o que parecia estranho, uma vez que esse casamento poderia salvar a familia da ruína financeira a que tinham levado os negócios do pai. $\mathrm{Na}$ origem da oposição está o facto de os jovens serem (meio) irmãos, fruto de um acto de adultério do pai da jovem. A peça termina com a revelação da verdade ao jovem e
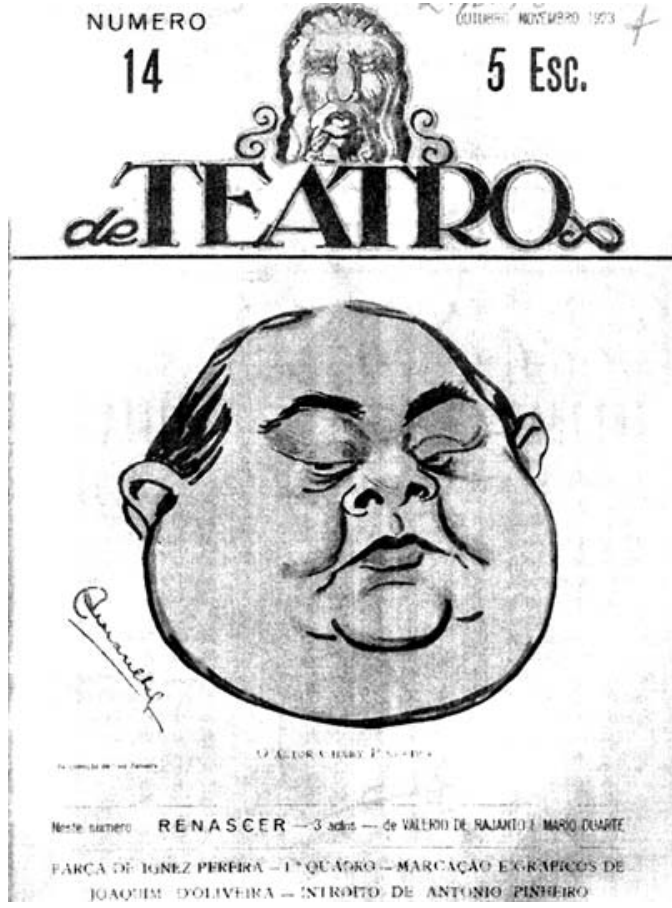

a morte do adúltero. 0 tema é recorrente, sendo mais uma vez analisada a corrupção moral dos tempos que se viviam, o tema do incesto, bem como a vertigem do mundo dos negócios.

0 amor entre jovens - que pode conflituar com a relação familiar - surge também numa peça de Ester Leão. Actriz de profissão, escreveu um inocente episódio em um acto, intitulado História de boneca, onde a autora procurou denunciar a hipocrisia da moral burguesa. A peça estreou a 25 de Abril de 1923, no Teatro Politeama, por ocasião da festa da actriz Constança Navarro, pela companhia Rey Colaço - Robles Monteiro. 0 conflito dramático assenta na não-aceitação, por uma jovem adoptada, do papel que lhe caberia enquanto pertencente à alta burguesia. Esta jovem, que, apesar de tudo, não deixa de corresponder ao estereótipo da ingénua, toma a iniciativa sexual junto do seu irmão adoptivo, que verdadeiramente ama, e acaba por conseguir que triunfe o seu amor, preterindo um casamento combinado pela sua mãe. Trata-se de uma apologia da espontaneidade por oposição às convenções burguesas.

É do jornalista Norberto de Araújo ${ }^{8}$ a peça Dentro do castigo, estreada a 14 de Maio de 1924, pela companhia societária do Teatro Nacional. Nela o autor aborda a questão do adultério (outra Helena dividida entre dois homens) que, todavia, não chega a consumar-se. Com efeito, a mulher se, inicialmente, se mostrava insatisfeita com o marido - um homem mais velho e que tinha uma actividade política - e fugira com um amigo do casal, mais tarde acaba por voltar, arrependida, vindo a ser perdoada pelo esposo. A peça aborda ainda os temas do amor não correspondido e do suicídio, por desespero, do amante "maldito". É curiosa nesta peça a correspondência entre a intervenção política do marido traído e a sua vida amorosa: se num primeiro momento, o marido, ao ver-se traído, decide abandonar a política por achar que, com o triunfo da República, se tinham perdido os ideais, acaba por perdoar à mulher, recompondo assim a harmonia na sua casa e regressando às suas convicções e ao activismo 


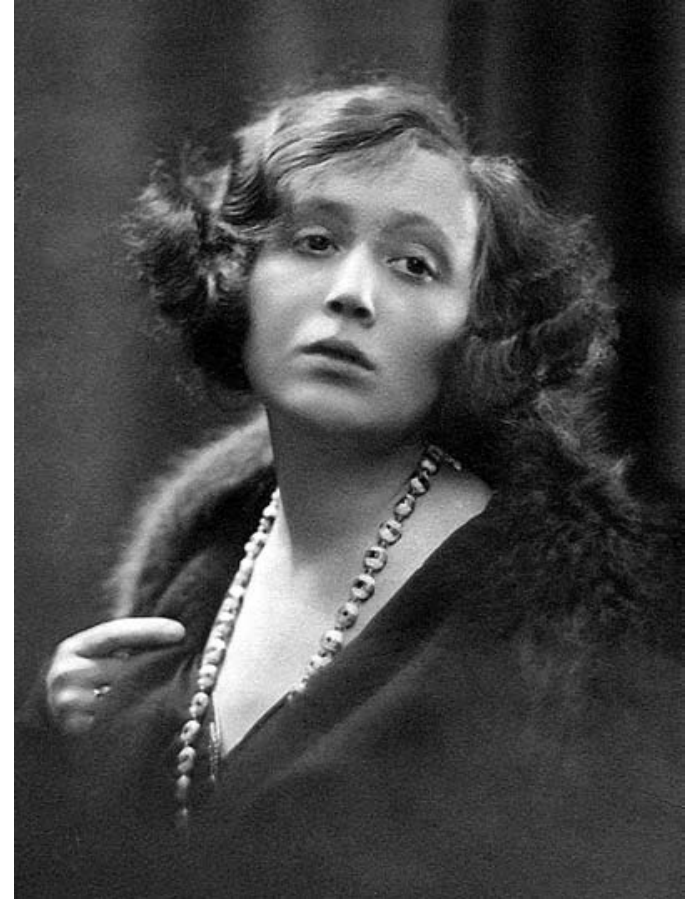

político como se amor e política fossem, afinal, duas causas que exigem uma luta constante.

Tito Arantes, advogado e deputado durante a ditadura salazarista - da qual era fiel adepto - viu ainda em estudante a sua peça de ambiente contemporâneo Os emigrantes estrear-se no Teatro Politeama, a 15 de Dezembro de 1921 pela companhia Lucilia Simões - Érico Braga. Os emigrantes tratados nesta peça são burgueses de moral corrupta que seduzem e raptam jovens inocentes, para depois as abandonarem em favor de uma amante. Helena é a jovem seduzida que se vê no final dividida entre o perdão do pai e a reconciliação com o marido que a abandonara. Nesta peça o divórcio, legalizado pela República, é condenado, e os filhos de casais divorciados apresentados como criaturas desrespeitadoras de qualquer autoridade moral. A figura feminina é valorizada como a guardiã da familia e dos valores tradicionais, sendo um solar na Beira o lugar onde vão entrar em oposição esses valores e a moral corrompida.

A peça $A$ intrusa, estreada a 12 de Janeiro de 1925, no Teatro da Trindade, pela companhia Palmira Bastos, é de Humberto Luna de Oliveira, oficial do exército e autor de dramas históricos, comédias e farsas, que colaborou ainda em operetas e revistas. Esta peça aborda a questão dos filhos ilegitimos que resultam de relações fortuitas, responsabilizando os homens que seduzem mulheres e depois as abandonam. É também colocada a questão do papel social das mulheres que trabalham fora de casa, situação que, não raras vezes, desperta o ciúme e o desprezo daquelas cuja situação económica é mais favorável e que, por isso, se mantêm no "recato" do lar. 0 amor contrariado de dois jovens empregados acaba por triunfar perante as adversidades, terminando a peça com a revelação de que a jovem, que tem de trabalhar para sobreviver, é de facto filha ilegitima do patrão.

0 cineasta Leitão de Barros (1896-1952), realizador de filmes tão marcantes como A Severa, Inês de Castro ou Camões, também tentou o teatro, e aqui interessouse pela questão do assédio sexual por parte de homens

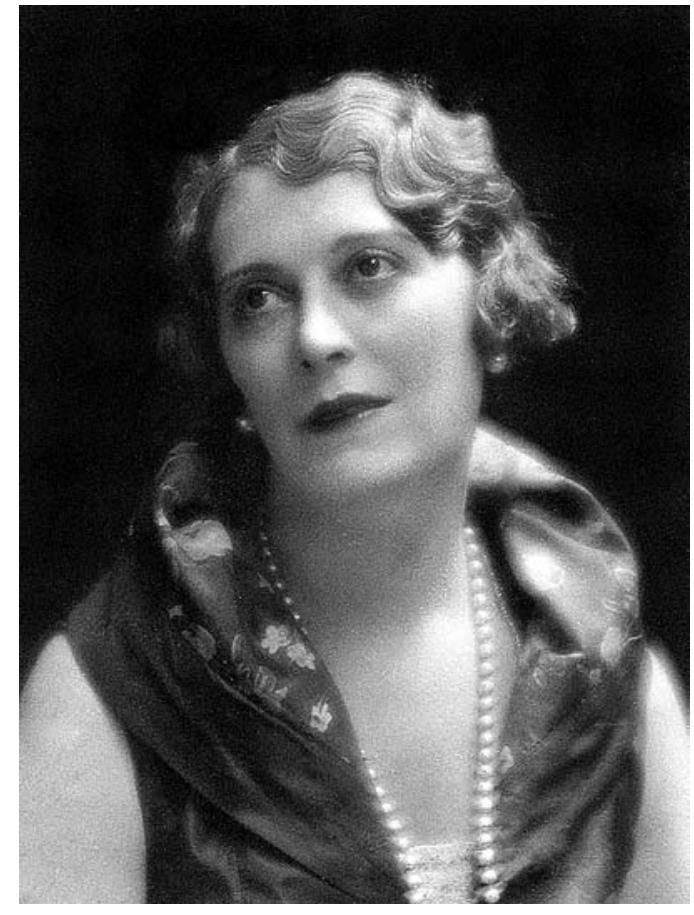

Amélia Rey Colaço [cortesia do Museu Nacional de Teatro].

sem escrúpulos relativamente a mulheres de condição social inferior que eles seduzem, engravidam e depois abandonam à sua sorte. Essa é a temática de 0 ramo das violetas, episódio em um acto, representado por Palmira Bastos e Amélia Bastos, em Maio de 1923, no Teatro S. Carlos. 0 mesmo tema surge na peça 30 H.P., estreada no Teatro Sá da Bandeira, no Porto, a 30 de Agosto de 1922 com Ilda Stichini e Samwel Diniz nos principais papéis. A acção passa-se em Lisboa e o espaço social é o das classes mais desfavorecidas. A mulher seduzida por um homem de posses (que não chega a comparecer em cena) arrepende-se e volta para o seu anterior companheiro, triunfando assim o amor puro e sincero. Em ambas as peças a figura feminina do povo surge como vítima de um sonho por uma vida melhor, aparentemente só possivel através da relação com um homem de condição social superior.

Mademoiselle Blá, estreada a 29 de Maio de 1925, no Teatro Politeama, pela companhia Rey Colaço - Robles Monteiro, é da autoria de Leopoldo Vale. Nesta obra, de duvidosa qualidade literária, o autor apresenta-nos uma mulher perversa, Maria Isabel que trabalha fora de casa, num mundo de homens. Talvez por se julgar indigna de casar, torna-se amante do seu protector e seduz um outro funcionário da empresa que tem casamento prometido com a afilhada do patrão. 0 tema do adultério é aqui, mais uma vez, dramatizado, sendo, no entanto, original quer a responsabilidade neste caso imputada à mulher, quer o arrependimento do homem adúltero, que confessa perante todos a traição que cometeu, livrando-se assim da chantagem de que era alvo.

Em 0 caso do dia, peça estreada em Dezembro de 1926, no teatro Ginásio, pela companhia Rey Colaço Robles Monteiro, Ramada Curto (1886-1961) apresentanos uma intriga que envolve as obscuras ligações do mundo dos negócios com a política. Tematiza ainda o poder dos jornais junto da opinião pública, recorrendo, se necessário, à calúnia para atingir os seus fins, o que neste caso visava fazer cair um ministro. Para a resolução do
Ester Leão

[cortesia do Museu Nacional de Teatro]. 
cento e vinte e seis

Retrato de Chaby Pinheiro

[cortesia do Museu

Nacional de Teatro].

Chaby Pinheiro

(1873-1952)

Óleo de Carlos Reis.

Adelina Abranches.

José Leitão de Barros.
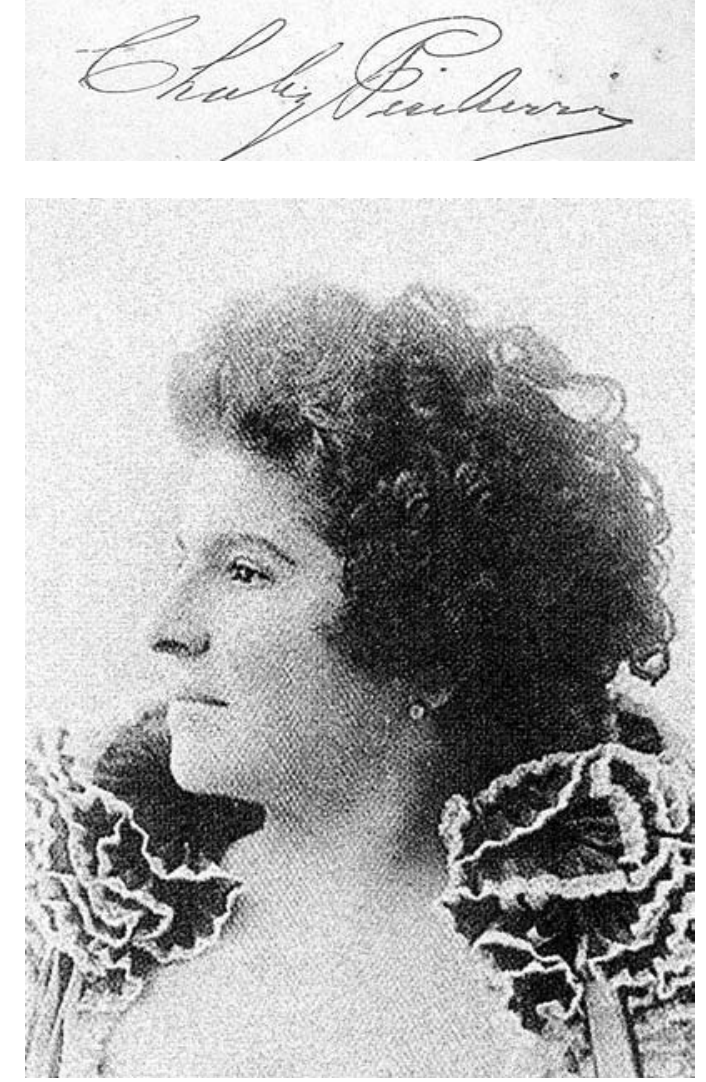

conflito assumem papel decisivo duas mulheres: Isabel (nesta peça o nome corresponde à boa indole da personagem) e Cármen, a amante do dono do jornal que consegue através de chantagem repor a justiça, redimindose, no final da obra, ao abdicar do seu interesse no flirt, deixando assim livre o caminho para o amor de Isabel. Outros ecos sociais que podemos ler nesta peça são: a problemática da mulher que trabalha num mundo de homens, a proibição de fumar nos locais de trabalho, a exploração do minério por parte dos ingleses e as greves dos mineiros associadas pela empresa a agitadores bolcheviques.

Aura Abranches (1896-1962) filha da grande actriz Adelina Abranches e do empresário teatral Luís Ruas,
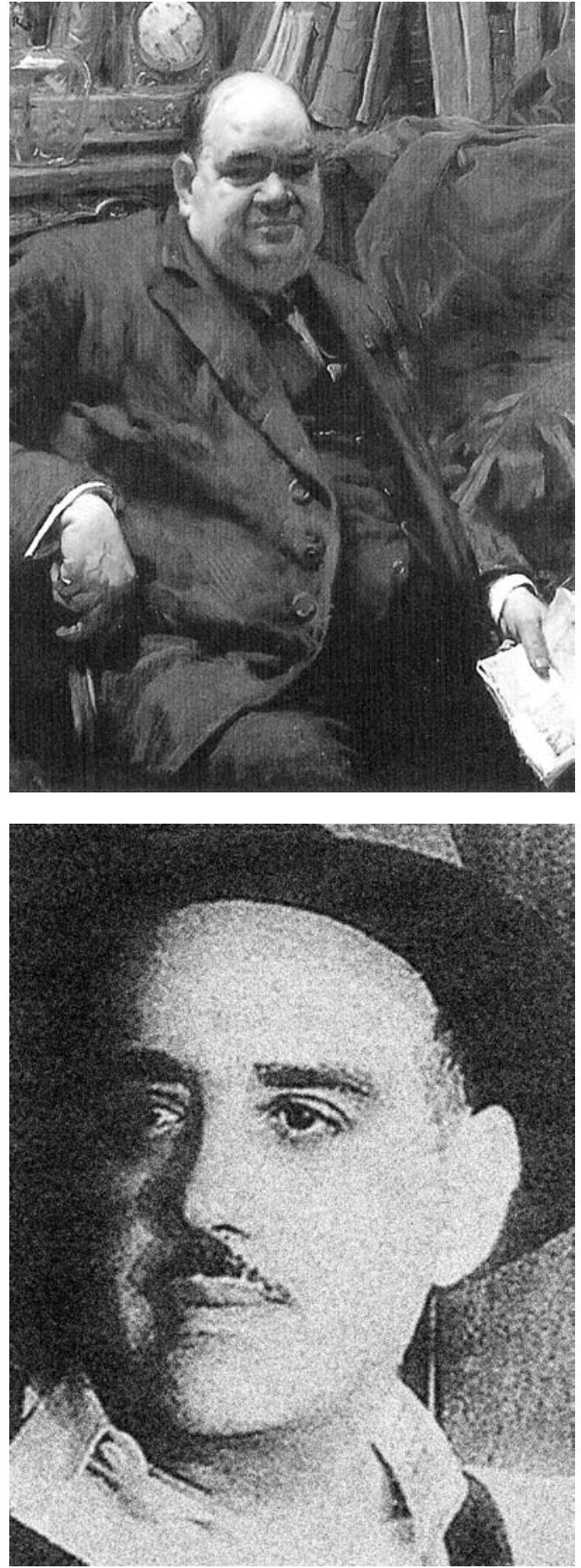

marcou o teatro português deste período mais como actriz do que como dramaturga, apesar das suas modestas tentativas neste domínio, como foi o caso de Madalena arrependida, estreada em 1922 no Teatro de Sant'Ana em S. Paulo e, mais tarde, apresentada em Portugal com Aura Abranches e a sua mãe nos principais papéis. É uma obra de fraca qualidade literária, onde o conflito não é suficientemente forte para manter a tensão dramática, embora se esforce por tematizar uma questão de alguma incidência social. Com efeito, Madalena arrependida denuncia a degradação moral da vida urbana por oposição à saudável (embora muito pobre) vida do campo. São ainda apresentadas preocupações de ordem social, como é o caso dos enjeitados, que se tornara um tópico relevante 


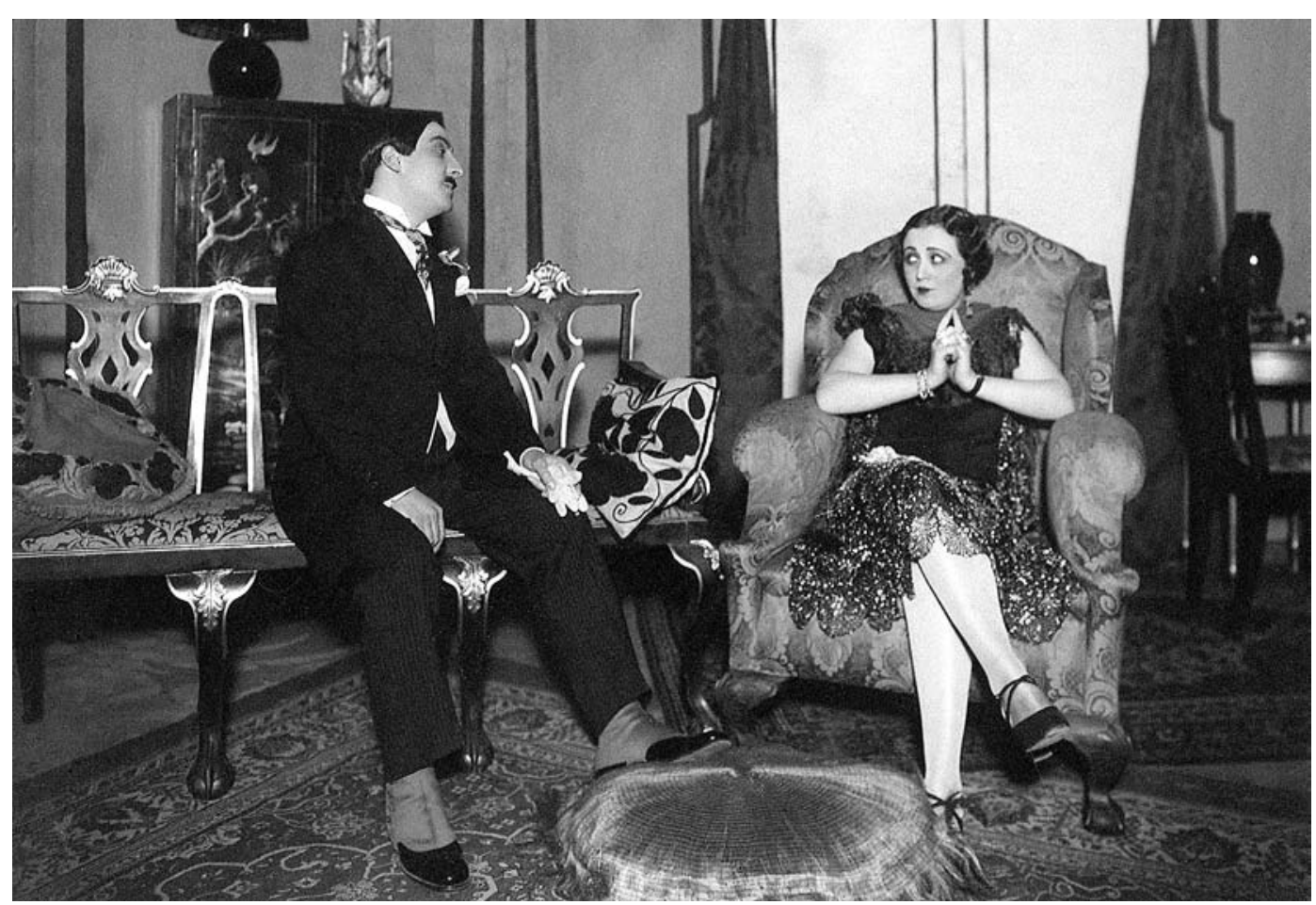

também no plano político e moral, uma vez que a República legalizara o reconhecimento de filhos ilegitimos. São também, e mais uma vez, criticados os sedutores que conquistam, sem escrúpulos, jovens inocentes. A peça é apresentada como uma comédia essencialmente por ter um final feliz: Madalena, a mãe perturbada, tal como a Madalena bíblica, arrepende-se e reconcilia-se com a filha que rejeitara. Todavia, este texto foge ao modelo típico das comédias da época onde imperavam os trocadilhos, o humor e os gracejos.

Em matéria de entrechos cómicos, destacaram-se neste periodo Carvalho Barbosa (1884-1936) e Arnaldo Leite (1886-1968) como sendo dos mais populares autores de comédias ligeiras, revistas e operetas do seu tempo, tendo ficado conhecidos como a Parceria do Porto, por oposição à Parceria de Lisboa (de Ernesto Rodrigues, Félix Bermudes e João Bastos). A farsa Cama, mesa e roupa lavada foi talvez a obra mais popular destes autores, estreada em 1922 e que deu oportunidade a Chaby Pinheiro de fazer uma interpretação memorável. Neste texto, que vive do trocadilho e do cómico de situação, os autores abordam o tema do divórcio, criando um protagonista que vive à custa da mulher de quem se vai divorciar. Compondo um enredo de equívocos e revelações, a peça mostra este homem a casar-se posteriormente com a filha ilegitima da sua primeira mulher. Todavia, e por razões compreensiveis, a sua jovem mulher, ao saber quem é a sua verdadeira mãe, pede também o divórcio. Enquanto aguarda pelos 365 dias exigidos pelo tribunal para decretar o divórcio, Aarão Saavedra consegue aquilo que procurava neste, como no anterior, casamento: cama, mesa e roupa lavada.

Pelo lado da Parceria de Lisboa ${ }^{9}$ não faltaram hilariantes comédias, revistas e operetas, quer originais quer adaptadas, que foram escrevendo entre $1912 \mathrm{e}$ 1926 para os palcos da capital com grande êxito na época. 0 amigo de Peniche é uma comédia de enganos onde é abordado o tema do adultério, bem como a esperteza do "amigo" de Peniche que consegue apossarse dos bens do amigo de Lisboa. São ainda tratadas, com grande actualidade, a questão da greve dos operários e das reivindicações dos inquilinos, havendo pelo meio, como não podia deixar de ser, uma história de amor com um final feliz.

$\mathrm{Na}$ caracterização do meio rural continua a ser dominante o tema do amor, mas a questão do assédio é mais claramente relacionada com a prepotência dos poderosos relativamente às classes mais baixas. Assim, por exemplo, Ramada Curto, no drama A fera, estreada em Setembro de 1923, no Teatro Politeama, pela companhia Berta de Bivar - Alves da Cunha, denuncia a actuação de um nobre que manda assassinar o namorado de $\mid$ sabe $^{10}$, filha da mulher que anos antes fora obrigada a casar com ele. Percebe-se nesta obra, de grande densidade dramática, que os motivos dominantes são, por um lado, o dos amores jovens contrariados, e, por outro, o da tentativa de incesto por parte de D. Diogo em relação a Isabel, deste modo focando a caracterização de um homem, de classe alta, que se revela prepotente, alcoólico e sem qualidades morais.

Coelho de Carvalho ${ }^{11}$ abordou, na peça A ponte, representada por alunos do Conservatório no Teatro Nacional Almeida Garrett, o tema da luta de classes ao apresentar uma pobre familia de pescadores explorada por um rico armador. Este assedia a afilhada que, para salvar a família da miséria em que se encontra, se lhe entrega, perdendo para sempre o homem que amava e que (saberá que erradamente) julgava morto no mar.

A peça Naúfragos, de Fernanda de Castro ${ }^{12}$, estreou a 27 de Abril de 1925, pela companhia societária do Teatro Nacional, tendo, de resto, sido distinguida pelo Prémio que este teatro atribuía. A acção da peça decorre num ambiente de pescadores e aborda o tema, recorrente, da condição da enjeitada e mal amada, que se apaixona por um dos filhos do homem que a adoptou. 0 amor, embora
${ }^{9}$ Ernesto Rodrigues (1875-1926), Félix Bermudes (1874-1960) e João Bastos (1883-1957).

${ }^{10}$ Reincidência no nome de Isabel referindo a jovem ingénua e pura.

${ }^{11}$ Coelho de Carvalho, nascido em 1855, foi jurista de profissão e chegou a ser Reitor da Universidade de Coimbra, tendo falecido em 1934.

${ }^{12}$ Fernanda de Castro, nascida em 1900, foi casada com o escritor $\mathrm{e}$ jornalista António Ferro, tendo escrito poesia,

teatro e diversos textos para a infância. Com uma destacada intervenção social no contexto do regime de Salazar, traduziu várias obras estrangeiras e publicou, com 85 anos, a sua autobiografia, Ao fim da memória (1906-1987). Faleceu em 1994. 


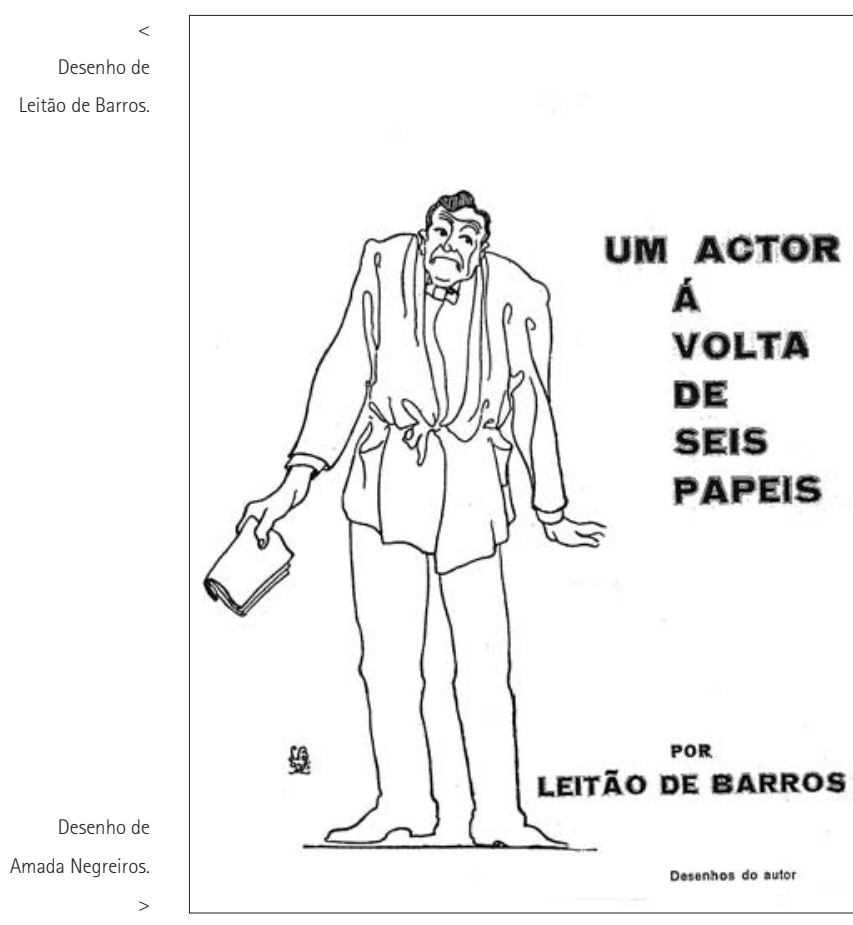

correspondido, é perturbado pelo assédio sexual que the move um outro irmão, decorrendo desta rivalidade entre irmãos a morte involuntária daquele que se interpunha entre os enamorados. Para além deste conflito amoroso, de final trágico, assinale-se ainda nesta peça o enaltecimento da bravura dos homens do mar, terminando a peça com a fuga do jovem par apaixonado.

De amores contrariados trata também a peça $A$ filha de Lázaro, escrita em co-autoria por Eduardo Chianca de Garcia $^{13}$ e Norberto Lopes ${ }^{14}$, e estreada a 31 de Março de 1925, no Teatro Politeama pela Companhia Rey Colaço Robles Monteiro com Raul de Carvalho e Ester Leão nos principais papéis. A acção decorre em ambiente rural,

nascido em 1898, entre outros, os seguintes filmes: $O$ trevo de quatro folhas, A Rosa do Adro, bem como a famosissima Aldeia da roupa brance em 1938, com Beatriz Costa num dos principais papéis. Veio a falecer em

${ }^{14}$ Norberto Lopes dedicou a sua vida ao jornalismo onde ocupou,

desde cedo, cargos de chefia nomeadamente no Diário de Lisboa em 1929 e n' A Capital em 1968. Traduziu várias peças

francesas e escreveu

algumas outras em parceria, mas ficou

essencialmente conhecido

pelas inúmeras eportagens que fez como

a Travessia Aérea do Atlântico Sul, em 1922, da Guerra Civil Espanhola. alternadamente entre uma casa de lavradores abastados e a casa de um pobre leproso (Lázaro, de seu nome, como na Bíblia). 0 ambiente rural é recriado nesta peça pela linguagem das personagens e pela singularidade de nomes como Ribas da Nóvoa (o rico lavrador prepotente e pai tirano), Rézio (o filho apaixonado e insubmisso), Belizária (a jovem filha do pobre leproso e apaixonada por Rézio). 0 conflito dramático, que atravessa toda a obra, assenta na luta pela posse das terras e na exploração dos pobres pelos ricos. 0 crime passional, involuntariamente cometido por Belizária, em nome de um amor contrariado, não é denunciado no final porque aqueles que o conheciam, comovidos com a sua capacidade de perdoar ao sogro que a tinha prejudicado na herança de uma fortuna em terras, se calam, reconhecendo o assassínio como um acto involuntário.

É em tom mais ligeiro, jocoso mesmo, que Chagas Roquette, em Frei Tomás - crónicas da aldeia, peça estreada a 28 de Janeiro de 1920 no Teatro Nacional pela companhia Rey Colaço -Robles Monteiro, nos apresenta uma divertida comédia rural, cheia de trocadilhos e de graças sobre a actualidade do país. A acção trata de amores antigos de dois velhos rabugentos que acabam por se resolver, não sem evitar um par de bofetadas que acalmam os ânimos da exaltada Liberata. Surgem também pequenas manobras políticas na aldeia onde se passa a acção e cómicas alusões

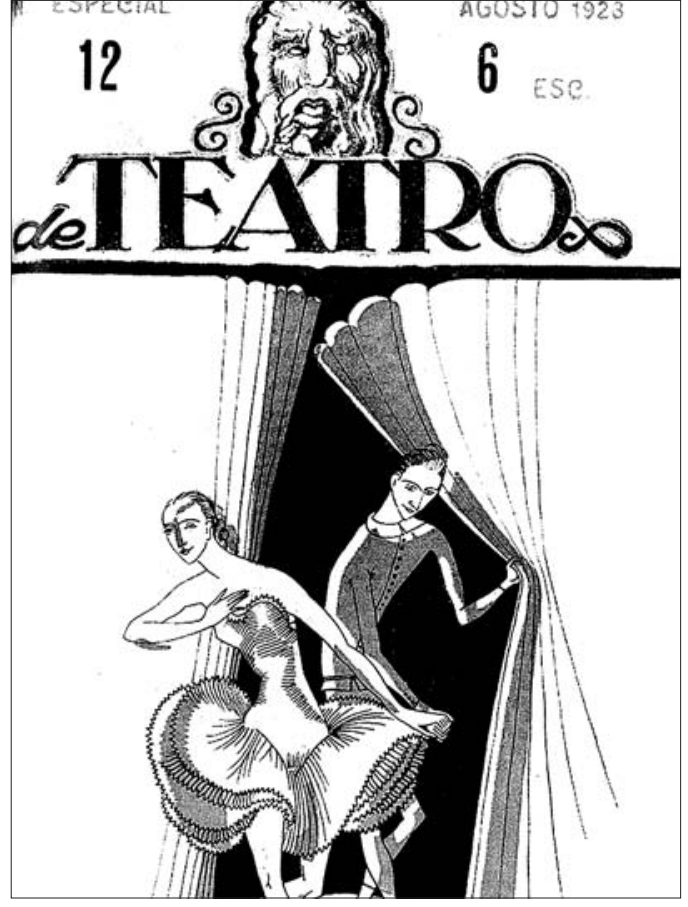

ao descalabro político em que se encontra o país. A peça termina com a reconciliação dos velhos e com o pedido em casamento de um jovem par amoroso que vira antes o seu amor contrariado.

Em jeito de conclusão

Nesta breve incursão por algumas das peças que a Revista De teatro - Revista de teatro e música publicou ao longo dos seus cinco anos de existência, verificamos que predominam as peças de costumes ainda presas a uma estética neo-romântica e naturalista e onde a tensão dramática se centra mais no diálogo do que na acção propriamente dita. É a Lisboa pequeno-burguesa nas suas ambições sociais, na incipiente industrialização e no complicado meio dos negócios que nos surge em imagem de fundo. Mas o tema obsessivamente tratado rodopia em torno de casos amorosos - adultérios, amores contrariados, abuso de poder, revelações fatais, etc. -, e a intenção é quase sempre de pregar a sacralidade do casamento e de defender a moral dos bons costumes. As personagens, de um modo geral, não ultrapassam os estereótipos que, de resto, apresentam um leque algo reduzido: a ingénua, 0 sedutor, a mulher fatal ou o oportunista sem escrúpulos.

Temas como a agitação política, as consequências da Primeira Guerra Mundial, o descalabro económico, a laicização do país (que a República permitiu), só muito tenuemente são aflorados. Afinal, ainda que se procure uma moralização social, é o entretenimento fácil o que mais se encontra nestas intrigas.

Salvo raras excepções, estes textos são de fraca qualidade literária e demasiado marcados historicamente para perdurarem no tempo. Correspondem, porém, a um projecto de dramaturgia que a revista De teatro promoveu e que, a seu modo, pretendia que desse uma visão da sociedade portuguesa de então. 0 que, provavelmente, ficou de mais significativo na dramaturgia portuguesa destes anos passou, todavia, ao lado da revista.

Há um caso, porém, que merece uma mais cuidada atenção: Um actor à volta de seis papéis (1925: 36). Trata- 

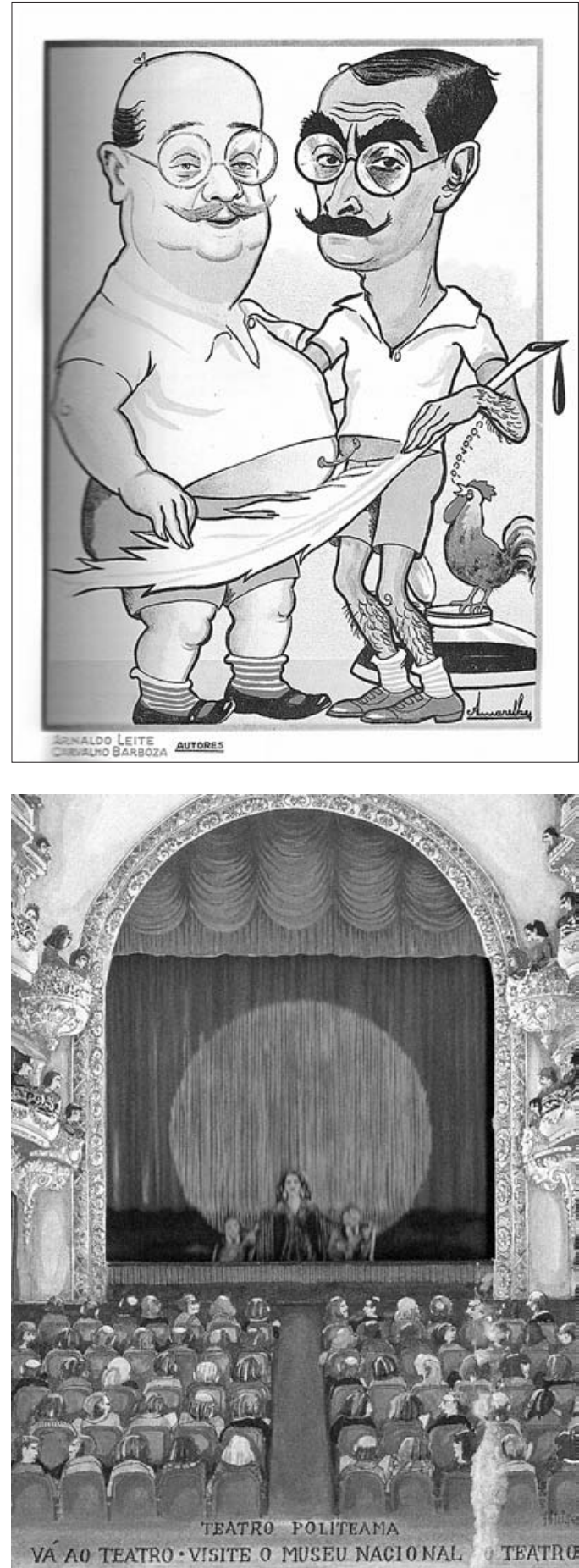

se da terceira peça de Leitão de Barros a ser publicada pela revista, e foi, tanto quanto se sabe, a primeira incursão em torno da obra de Pirandello em Portugal. Pelas suas características esta "réplica à parte anedótica, e só a esta, da famosa peça pirandelliana" (Seis personagens à procura de um autor, 1921), segundo as palavras do autor, apresenta-se como uma peça de ruptura em relação à maioria das obras dramáticas que a revista publicou.

0 autor reflecte sobre o teatro deste período, através da análise da relação actor-autor no processo de criação das personagens representadas e a legitimidade da intervenção de cada um nesse processo. Utilizando a técnica de teatro dentro do teatro, que vai desde o nível da representação - um teatro onde se acabou de representar uma peça do repertório tradicional, à qual assistiu o público presente na sala e onde se encontra o verdadeiro Leitão de Barros - passa-se, seguidamente para um segundo nivel, onde surgem os actores com os verdadeiros nomes, conhecidos pelo público, que entram em cena para representar uma cena da peça anterior. Ensaiam a cena, agora sem guarda-roupa nem cenários, o que corresponde ao terceiro nivel. Neste jogo, o autor põe em confronto um autor dramático, Director da Companhia, o Homem do Rolinho, ou seja o próprio Leitão de Barros, com o actor-personagem, Alexandre de Azevedo, a quem a peça, de resto, é dedicada. A peça termina com o assassínio do autor cometido pelo actor que rejeitava o texto pela sua falta de verosimilhança. Com este assassínio, o texto e a mensagem de Leitão de Barros acabam por se tornar verdade, rebatendo assim todos os argumentos do actor. Abordam-se, deste modo, muitas questões importantes do teatro de então, como a pressão a que as companhias estavam sujeitas ao aceitarem obras que não apreciavam por receio de serem penalizadas na imprensa, bem como as convenções de representação dos actores de então, e a sua incapacidade, por falta de formação adequada, de avaliar a qualidade dos textos que levavam à cena.

Uma imagem que, provavelmente, e salvo rarissimas excepções, não andaria muito longe da realidade do teatro de então.

\section{Referências bibliográficas}

REBELLO, Luiz Francisco (1984), Cem anos de teatro português, Porto, Edições Brasilia.

_- (2004), "Jornais e revistas de teatro em Portugal", in Sinais de cena, n. 1, Junho, APCT/CET, Porto, Campo das Letras, pp. 69-71. Revista De teatro - Revista de teatro e música, Lisboa, 1922-1927.
Arnaldo Leite

e Carvalho Barbosa, a "Parceria do Porto": desenho de Amarelhe.

Teatro Politeama: teatrinho de papel de Fernando Filipe. 


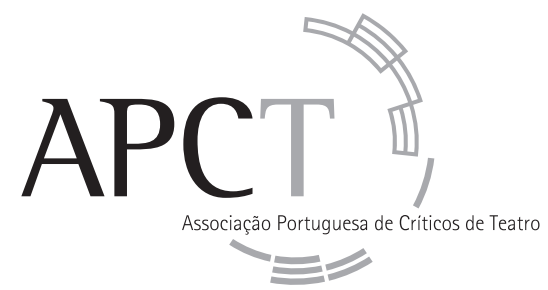

\begin{tabular}{c|l} 
Presidente honorário & Carlos Porto \\
Direcção & $\begin{array}{l}\text { Maria Helena Serôdio } \\
\text { Paulo Eduardo Carvalho } \\
\text { João Carneiro }\end{array}$
\end{tabular}

Assembleia Geral $\quad$ Luiz Francisco Rebello

Sebastiana Fadda

Conselho Fiscal Ana Isabel Vasconcelos

Mónica Guerreiro

Rui Pina Coelho

\begin{tabular}{l|l} 
ESTATUTOS & Capítulo Primeiro (Da Associação e dos seus fins)
\end{tabular}

Art. ${ }^{2} .^{\circ}$

A Associação tem por objectivo:

Dignificar, estruturar e responsabilizar a actividade crítica relativa à teoria e prática do teatro, entendendo-se por actividade crítica não só a crítica de espectáculos, mas também tudo aquilo que diga respeito à informação, reflexão e teorização no campo das artes performativas.

\section{Colaboração com Sinais de cena}

A revista está aberta à participação de quem deseje colaborar enviando artigos que julgue corresponderem aos objectivos da publicação e às modalidades enunciadas pelas rubricas existentes. A consulta do sítio da APCT na Internet (www.apcteatro.org) e o contacto por correio electrónico (estudos.teatro@fl.ul.pt) são indispensáveis para conhecer as normas de apresentação dos artigos (dimensão, aspecto gráfico, citações, referências bibliográficas, ilustrações, etc.).

\section{ASSINATURA}

Desejo subscrever os números 8 e 9 da revista Sinais de cena (correspondentes a Dezembro de 2007 e Junho de 2008), no valor total de $22,00 €$ beneficiando assim de um desconto sobre o preço de venda ao público.

Fora do pais: Europa $24,00 €$ / Fora da Europa $26,00 €$.

Nome:

Morada:

Lódigo postal: $\quad$ Pais:

Endereço electrónico:

\begin{tabular}{l|l|l|} 
Forma de pagamento: $\quad \square$ Vale postal $\quad \square$ Cheque $n^{\circ}$. & Banco
\end{tabular}

(passar à ordem de Associação Portuguesa de Críticos de Teatro)

Preencha e envie este cupão (ou fotocópia do mesmo) para:

Data:

\section{Sinais de cena}

Centro de Estudos de Teatro

Faculdade de Letras de Lisboa: sala 67

Alameda da Universidade

1600-214 Lisboa (Portugal) 